deficiency $^{\circ}$ and reflects the importance of this serine protease inhibitor for the anticoagulant activity of heparin.

Our experience shows the importance of screening for an underlying disorder in the young with thrombosis and strongly suggests that prophylactic measures aimed at preventing thrombosis should be considered in acutely ill subjects with infection and familial thrombophilia.
1 Rosenberg RD. Actions and interactions of antithrombin and heparin. N Engl J Med 1975;292:146-51

2 Odegard OR, Abildgaard U. Antithrombin III: Critical review of assay methods. Significance of variations in health and disease. Haemostasis 1978;7:127-34.

3 Lechner K, Thaler E, Niessner H, Nowotny C, Portsch H. Antithrombin III mangel und thromboseneigung. Wien Klin Wochenschr 1977;89:215-22.

4 Egeberg $O$. Inherited antithrombin deficiency causing thrombophilia. Thromb Diath Haem 1965;13:516-30.

5 Hirsch J. Congenital antithrombin III deficiency. Am J Med 1989;87(suppl 3B):34-8.

6 Filip DJ, Eckstein JD, Veltkamp JJ. Hereditary antithrombin III deficiency and thromboembolic disease. $A m \mathrm{~J}$ Hematol 1976;2:343-9.

\title{
No evidence of HTLV-I infection in French patients with multiple sclerosis using the polymerase chain reaction
}

\author{
E Wattel, M Mariotti, J D Bignon, F Agis, E Gordien, J Y Muller, J Hors, J J Lefrère
}

Institut National de Transfusion Sanguine, Rue AlexandreCabanel, 75015, Paris, France

E Wattel

M Mariotti

J J Lefrere

Centre de Transfusion de Nantes, Allée Charles-Mirallié, Nantes, France J D Bignon J Y Muller

Centre de Transfusion, Guadeloupe, West

Indies

F Agis

E Gordien

Laboratoire de Génétique, Hôpital Saint-Louis, Paris, France

J Hors

Correspondence to: Dr Jean-Jacques Lefrère Accepted for publication 4 April 1991

\begin{abstract}
The polymerase chain reaction (PCR), using three primer pairs in the pol, tax, and $e n v$ regions of the HTLV-I genome, was unable to detect HTLV-I in the blood samples of 54 caucasian subjects with multiple sclerosis who were seronegative for HTLV-I/II. Seventeen HTLV-I/II seropositive (by ELISA and Western blot) subjects used as positive controls were positive with the three primer pairs. The PCR was negative in 47 healthy HTLV-I/II seronegative (by ELISA) subjects at low risk of HTLV-I infection used as negative controls.

These results suggest that there is no association between the occurrence of HTLV-I sequences and the development of multiple sclerosis.
\end{abstract}

The serological association between human T-lymphotropic virus type I (HTLV-I) infection and a chronic neurological disease such as the tropical spastic paraparesis prompted a search for this infection in other chronic neurological disorders such as multiple sclerosis (MS). The presence of specific antibodies ${ }^{12}$ and of HTLV-I sequences determined by in situ hybridisation $^{1}$ in patients with $M S$ has been disputed. ${ }^{3-4}$ Recently, Reddy ${ }^{5}$ and Greenberg, ${ }^{6}$ using gene amplification by the polymerase chain reaction (PCR), showed HTLV-I DNA sequences $^{5}$ or related retrovirus $^{6}$ in the peripheral blood mononuclear cells of patients with MS who were seronegative for HTLV-I.
As these results have not been confirmed by others, however, ${ }^{78}$ Reddy suggested that these discrepancies could have been due to the fact that only a subgroup of such cases could harbour HTLV-I sequences. ${ }^{5}$

Doubts therefore persist as to the possible relation between HTLV-I infection and MS. We decided to study a large number of French patients with MS to see if HTLV-I sequences could be detected using a PCR assay, to check if epidemiological differences could explain the discrepancies in previously published assays.

\section{Methods}

Fifty four caucasian adults with $M S$, as defined by Poser et $a l^{9}$, were studied. Mean age at onset of disease was 29.4 years; mean age at the time of the study was $42 \cdot 2$ years; 17 were male. All were seronegative by ELISA for antibodies to HTLV-I/II. None had a history of blood transfusions.

Seventeen HTLV-I/II seropositive (by ELISA) subjects living in an endemic region of HTLV-I/II infection (Guadeloupe, French West Indies) and showing typical patterns of HTLV-I/II infection on Western blotting were used as positive controls. Forty seven healthy HTLV-I/II seronegative (by ELISA) subjects (blood donors), living in a nonendemic area (Paris), and with no risk factors for HTLV-I/II infection were used as negative controls.

\section{DNA EXTRACTION}

DNA was prepared from $5 \mathrm{ml}$ of fresh or 
frozen peripheral blood. Red cells were lysed by a hypotonic buffer (TRIS- $\mathrm{HCl} 10 \mathrm{mmol} / \mathrm{l}$, $\mathrm{pH}=8.6$; magnesium chloride $10 \mathrm{mmol} / \mathrm{l}$; sodium chloride $10 \mathrm{mmol} / \mathrm{l}$ ). The resulting pellet was washed with the same buffer. DNA was extracted after treatment of the cells in lysis buffer (TRIS-HCl $10 \mathrm{mmol} / \mathrm{l}, \mathrm{pH}=8.6$; EDTA $10 \mathrm{mmol} / 1, \mathrm{pH}=8$; sodium chloride $10 \mathrm{mmol} / \mathrm{l}$; sodium dodecyl sulphate $0.5 \%$; proteinase $\mathrm{K} 100 \mu \mathrm{g} / \mathrm{ml}$ ) at $42^{\circ} \mathrm{C}$ overnight. After phenol and chloroform isoamyl alcohol ( 1 in 24 ) treatment the DNA was precipitated with ethanol and resuspended in a solution of TRIS-HCl $\quad(10 \mathrm{mmol} / \mathrm{l}, \quad \mathrm{pH}=7.5) \quad$ and EDTA (1 mmol/l).

\section{PRIMERS AND PROBES}

The primers used for PCR amplification and the probes used to detect amplified sequences were derived from the pol, tax, and env regions of HTLV-I sequences: (i) The two pol primers were SK54 and SK $55^{10}$ and would be expected to amplify the region between nucleotides (nt) 3365 to 3483 of the sequence described by Seiki. ${ }^{11}$ The oligonucleotide probe was SK56, which spans the region between nt 3426 and 3460 . (ii) The two env primers have been previously described ${ }^{5}$ and would be expected to amplify the region between nt 5684 to 6151 of the HTLV-I sequence. The oligonucleotide probe was SG $228,{ }^{6}$ which spans the region between nt 5841 and 5880. (iii) The two tax primers were SK43 and SK $44^{9}$ and would be expected to amplify the region between nt 7358 to 7516 of the HTLV-I sequence. The oligonucleotide probe was SK45, ${ }^{9}$ which spans the region between nt 7447 and 7486 of HTLV-I sequence.

\section{PCR METHODOLOGY}

Amplification of specific fragments by PCR with thermostable Taq DNA polymerase was carried out as follows: $100 \mu \mathrm{l}$ reaction volumes contained $1 \mu \mathrm{g}$ genomic DNA in $1.0 \mathrm{mM}$ TRIS- $\mathrm{HCl}(\mathrm{pH}=8.3), 2.5 \mathrm{mM} \quad \mathrm{MgCl} 2$, $200 \mu \mathrm{M}$ of each dNTP (dATP, dCTP, dGTP, dTTP), $0.2 \mu \mathrm{mol} / 1$ of each primer and 2.5 units of enzyme. The samples were overlaid with several drops of mineral oil and subjected to 35 cycles of amplification: DNA denaturation was carried out at $94^{\circ} \mathrm{C}$ for one minute; annealing of primers was carried out at $59^{\circ} \mathrm{C}$ for one and a half minutes; extension of the two primers was carried out at $72^{\circ} \mathrm{C}$ for one and a half minutes. To prevent contamination, negative controls were included in each run, and a control reaction looking for a single copy cellular gene-for example, $\beta$ globin was performed with each sample to ensure that the DNA was amplifiable. We tested our strategy with an MT-4 cell line infected with HTLV-I. Analysis of amplification products was studied through slot blotting and Southern blotting (from a $2 \%$ agarose gel). The gel was stained with ethidium bromide and photographed under ultraviolet light, showing a specific band.

\section{Results}

Patients with MS did not have evidence of HTLV-I sequences with the three primer pairs used. The $17 \mathrm{HTLV}-\mathrm{I} / \mathrm{II}$ seropositive subjects were all positive for HTLV-I with primer pairs in pol, tax, and env regions. The polymerase chain reaction assay was negative with the same primer pairs in the 47 healthy HTLV-I/II seronegative subjects who acted as negative controls.

\section{Discussion}

In the controls amplification was specific for HTLV-I sequences and no amplification of non-specific sequences occurred. Our results in patients with MS conflict with those of Reddy ${ }^{5}$ and Greenberg, ${ }^{6}$ and confirm those of Bangham $^{7}$ and Richardson. ${ }^{8}$ These discrepancies are difficult to explain. As some cases of tropical spastic paraparesis for which the association with HTLV-I infection has been confirmed can clinically resemble multiple sclerosis, HTLV-I positive MS might have been tropical spastic paraparesis. Furthermore, the exquisite sensitivity of the PCR assay is such that DNA contamination from the laboratory can lead to false positive results. In Reddy's study ${ }^{5}$ one of the 20 negative controls showed detectable HTLV-I sequences.

Our data strongly suggest that an association between the occurrence of HTLVI sequences and the development of multiple sclerosis is unlikely. Nothing suggests that this retrovirus may be responsible for MS. We conclude that the discrepancies of results suggest that a quality control for laboratories using the PCR in HTLV-I is indispensable.

We thank L Prin for the MT4 cell line infected with HTLV-I, and AM Couroucé and O Prou for HTLV-I serology (Western blotting). We also thank Annick Alperovitch and the French research group on multiple sclerosis for providing the blood samples from patients.

1 Koprowski H, Defreitas EC, Harper ME, et al. Multiple sclerosis and human T-cell lymphotropic retroviruses. Nature $1985 \cdot 318: 154-60$

2 Ohta M, Ohta K, Mori F, Nishitani H, Saida T. Sera from patients with multiple sclerosis react with human $\mathrm{T}$-cell patients with multiple sclerosis react with human T-cell lymphotropic virus-T gag protein but not env protein

3 Karpas A, Kämpf U, Sident A, Koch M, Poser S. Lake of evidence for involvement of known human retroviruses in evidence for involvement of known human

multiple sclerosis. Nature 1986;322:177-8.
Gessain A, Abel L, DeThe G, Vernant JC, Raverdy P, Guillard A. Lack of antibodies to HTLV-I and HIV with multiple sclerosis from France and French West Indies. BrMed J 1986;293:424-5.

5 Reddy EP, Sandberg-Wollheim M, Mettus RV, Ray PE, Defraitas E, Koprowski H. Amplification and molecular cloning of HTIV-I sequences from DNA of multiple sclerosis patient Science 1989:243:529-33.

6 Greenberg SJ, Ehrlich GD, Abbott MA, Hurwitz BJ, Waldman TA, Poiesz BJ. Detection of sequences homologous to human retroviral DNA in multiple homologous to human retroviral DNA in multiple sclerosis by gene

7 Bangham CRM, Nightingale S, Cruickshank JK, Daenke S. PCR analysis from multiple sclerosis patients for the PCR analysis from multiple sclerosis pati

8 Richardson JH, Wucherpfennig KW, Endo N, et al. PCR analysisof DNA from multiple sclerosis patients for the analysisof DNA from multiple sclerosis patien
presence of HTLV-I. Science 1989;246:821-3.

9 Poser CM, Paty D, Scheinberg L, et al. New diagnostic criteria for multiple sclerosis: guidelines for research protocols. Ann Neurol 1983;13:227-31.

0 Duggan DB, Ehrlich GD, Davey FP, et al. HTLV-I induced lymphoma mimicking Hodgkin's disease. Diagnosis by polymerase chain reaction amplification of specific HTLV I sequences in tumor DNA. Blood 1988;71:1027-32.

11 Seiki M, Hattori S, Hirayama Y, Yoshida M. Human adult T-cell leukemia virus: complete nucleotide sequence of the provirus genome integrated in leukemia cell DNA. Proc Natl Acad Sci USA 1983;80:3618-22. 